This is a self-archived - parallel published version of this article in the publication archive of the University of Vaasa. It might differ from the original.

\title{
Self-discovery enabling entrepreneurial discovery processes
}

Author(s): Virkkala, Seija; Mariussen, Åge

Title: $\quad$ Self-discovery enabling entrepreneurial discovery processes

Year: $\quad 2018$

Version: Accepted manuscript

Copyright (C)2018 Routledge. This is an Accepted Manuscript of a book chapter published by Routledge in The entrepreneurial discovery process and regional development : new knowledge emergence, conversion and exploitation on 20 December 2018, available online: http://www.routledge.com/978-1-351-273763

\section{Please cite the original version:}

Virkkala, S., \& Mariussen, Å., (2018). Self-discovery enabling entrepreneurial discovery processes. In: Mariussen, A., Virkkala, S., Finne, H., \& Aasen, T.M., (eds), The entrepreneurial discovery process and regional development : new knowledge emergence, conversion and exploitation (1134). Routledge. https://doi.org/10.4324/9781351273763 


\title{
Self-discovery enabling entrepreneurial discovery processes
}

\author{
Seija Virkkala and Åge Mariussen
}

\section{Introduction}

The future is unknowable and the global environment turbulent. Nobody is capable of presenting an overall view of how technological and market opportunities will influence regional development. The solution to this dilemma proposed by the EC smart specialisation policy involves governments, companies, universities, and other actors or quadruple helix stakeholders uniting to identify future growth opportunities (Radosevic, 2017b; Foray, 2017). The method governing that search is the entrepreneurial discovery process (EDP), which is a collective idea generation mechanism addressing the future of the region in terms of the knowledge economy. The EDP and smart specialisation have the same meaning as practices and approaches to diversify the regional economy. The aim is to expand the regional economy in a direction identified by the relevant quadruple helix stakeholders (i.e. entrepreneurial actors). This is a pressing policy concern, particularly at times of significant restructuring in the world economy, given the relatively slow transition to a more prosperous knowledge economy in parts of Europe.

Regional development is often considered in economic terms as a question of growth, but in this book it is defined more broadly in line with the Europe 2020 targets for smart sustainable and inclusive growth as also addressing social and ecological policies like diminishing social inequality, promoting environmental sustainability and championing inclusive government. The broader definition includes implementing smart specialisation strategies (S3).

Development is a change of direction but smart specialisation and EDP particularly emphasise the renewal of the regional economy. S3 is an economic transformation agenda built on each region's strengths. The new business areas or fields of opportunity (domains) which are discovered through the broad partnership are expected to initiate structural changes in different forms: diversification, transition, modernisation, or the radical foundation of industries and/or services (Foray, 2015:1), in other words path renewal, path extension or new path creation in the terminology of economic geography. (see Isaksen et al., 2019).

According to the Smart Specialisation Platform (EC-JRC, 2017):

The EDP is an inclusive and interactive bottom-up process in which participants from different environments (policy, business, academia, etc.) are discovering and producing information about potential new activities, identifying potential opportunities that emerge through this interaction, while policymakers assess outcomes and ways to facilitate the realisation of this potential. The EDP pursues the integration of entrepreneurial knowledge fragmented and distributed over many sites and organisations, companies, universities, clients and users, specialised suppliers (some of these entities being located outside of the region) through the building of connections and partnerships. The EDP consists of the exploration and opening up of a new domain of opportunities (technological and market), potentially rich in numerous innovations that emerge as feasible and attractive.

The notion of the EDP can be viewed from different perspectives. Rodríguez-Pose and Wilkie (2017) have related the concept of the EDP to an institutional approach by decomposing EDP 
into three elements (entrepreneurial actors, experimentation and discovery, and the interaction between relevant actors) and exploring the way that institutions interact with these components. They also point to the need to adapt EDP to contextual factors (see also Gianelle et al., 2016). Others, like Morgan (2017b) and Aranguren et al. (2017) explore the human element in smart specialisation governance. Aranguren et al. (2017) examine the concept of smart specialisation with the aid of leadership theories and emphasise the process view on governance.

The notion of self-discovery is related to the EDP and emphasises the concept of agency. Hausmann and Rodrik (2003) state that self-discovery means to discover what economic activities can profitably be pursued in a given country, given the existing strengths and specialisations of the national economy. The latent competitive advantage of nations or regions can be discovered in broad partnerships. In terms of regional development policies, self-discovery refers to a region's strengths and unique assets that can form the basis for future business fields.

This book highlights the relations between exploitation and exploration in the context of EDP. Exploitation refers to using existing knowledge to refine existing processes; exploration refers to the discovery and creation of new knowledge. Exploitation crowds out exploration and vice versa (March, 1991). Strong clusters tend to lead to exploitation rather than exploration. Innovation systems oriented towards exploitation may restrict entrepreneurs who try to create new paths. This is where the EDP can contribute by pushing innovation policy and research supporting innovation policy in the direction of more exploration.

This book aims to answer the research question: How is the transition from exploitation of knowledge to exploration and discoveries possible, and what are the implications for the actors involved, for the transformation of the regional economy, and for knowledge production and creation?

This chapter examines what the 'self' in self-discovery is; more specifically it investigates what is required for actors to make the transition from exploitation to discoveries in regional development (Table 1.1). Chapter 9 (Virkkala and Mariussen, 2019) analyses the implication of this transition to exploration for the transformation process of regional economy, and Chapter 5 (Lam, 2019) and Chapter 8 (Virkkala, 2019) focus on the knowledge creation and knowledge space needed for the discovery. The actors, the process, and knowledge are indistinguishable elements of the same processes despite being addressed separately for the purposes of analysis. In real-life EDPs, these analytical elements interact in the processes of exploration, failures, success and exploitation.

This chapter focuses on self-discovery enabling the EDP. The EDP begins with fragmented knowledge that must be combined, and which, together with additional knowledge resources, is necessary for exploration. The EDP is a move from a state of knowledge and actor fragmentation to a process of self-discovery. Along that road, the fragments of knowledge objects come together into a new, living entity, knowledge as process that offers a new cognitive understanding of the opportunities available to a region. The start of this journey of self-discovery requires a creation of a collective actor capable of pulling things together and in that way that makes sense of the opportunities available to the regional economy in a new way. This point of departure will be discussed in the second section of this chapter, which gives an overview of the process from fragmentation (of knowledge) in the exploitation phase to emergence of a new domain of opportunities for new value creation. In the third section of 
this chapter, EDP and S3 will be compared with approaches often used in regional development strategies: the cluster approach and the innovation system approach. EDP is an attempt to overcome the shortcomings of policies based on theories of regional innovation system or RIS. The RIS tradition has been criticised for being too static and not providing relevant policy advice. The RIS literature 'is nearly silent on the conditions that enable growth to accrue in regions where innovation occurs' (Doloreux and Porto Gomez, 2017).

The fourth section of the chapter summarises some critical reflections on the EDP. This chapter presents preconditions that can trigger a change from exploitation to exploration in which the EDP provides a potential solution. The first precondition is to change the static structure to a more complex and dynamic process by moving focus and policy measures from the micro level to the macro level. The second precondition is to recognise the tacit character of knowledge as well as the interaction processes leading to the knowledge spiral, in other words, a continuous EDP. The third precondition is to make the EDP a transnational discovery process. These preconditions can be seen as challenges meriting further examination and will be discussed thoroughly in the later chapters of the book.

Table 1.1 Framing elements of the regional self-discovery process (EDP)

\begin{tabular}{llll}
\hline & $\begin{array}{l}\text { Static point of departure } \\
\text { Exploitation } \\
\text { Clusters }\end{array}$ & $\begin{array}{l}\text { Road to discovery } \\
\text { Exploration } \\
\text { RIS3 }\end{array}$ & $\begin{array}{l}\text { Theoretical approaches } \\
\text { Regional innovation systems } \\
\text { Entrepreneurial discovery processes }\end{array}$ \\
\hline Actors & $\begin{array}{l}\text { Individual (division of } \\
\text { labour) }\end{array}$ & $\begin{array}{l}\text { Collective (triple } \\
\text { helix) regional actors }\end{array}$ & $\begin{array}{l}\text { Triple and quadruple helix (Chapters 1, 3, } \\
\text { 4) }\end{array}$ \\
EDocess & $\begin{array}{l}\text { Efficient structures of } \\
\text { exploitation }\end{array}$ & $\begin{array}{l}\text { Emergence of new } \\
\text { opportunities }\end{array}$ & $\begin{array}{l}\text { Self as public-private alliance (Chapter 1) } \\
\text { Complexity approaches (Chapter 7) }\end{array}$ \\
Knowledge & $\begin{array}{l}\text { Knowledge as object, } \\
\text { specialisation }\end{array}$ & $\begin{array}{l}\text { Knowledge as process, emergence (Chapter 9) } \\
\text { sensemaking and } \\
\text { conversion }\end{array}$ & $\begin{array}{l}\text { SECI process (Chapters 7, 8) } \\
\text { Third spaces (Chapter 5) } \\
\text { Knowledge spaces (Chapter 8) }\end{array}$ \\
\hline
\end{tabular}

Source: Own elaboration

\section{The EDP: collective actors searching for new domains}

\section{Background of the notion of the EDP}

In order to understand the role of collective actors in the EDP, this chapter first introduces the background of the EDP in a stylised way. The concepts of entrepreneurial opportunities and discoveries are used in business and entrepreneurship studies (Shane, 2003) and they originate from Austrian economists like Hayek - and Kirzner (1973; 1997).

Entrepreneurs are continually searching for, identifying and evaluating new business opportunities. This process is called entrepreneurial discovery in the business theory literature (Shane, 2003:3-6). Entrepreneurship requires the existence of opportunities, or situations in which people think that they can recombine resources to generate profits. Entrepreneurship can be characterised as the reaction of certain individuals (entrepreneurs) to the existence of opportunities for profit. However, the exploitation of opportunity is uncertain because it 
depends on demand, competition and the opportunity to create a value chain. The individual entrepreneur exploits an opportunity and organises and recombines resources in a way that they have not been previously. The opportunities an entrepreneur exploits are created for instance by social/demographic change, technological change, and political/regulatory change, as well as by grand challenges like climate change (Shane, 2003).

The Austrian economists saw market equilibrium as a process through which market participants acquire accurate knowledge of potential demand and supply. The Austrian approach nominates entrepreneurial discovery as the driving force behind the process. Kirzner (1973) pointed out that opportunities are discovered through entrepreneurial alertness, and that better knowledge leads to competition and a new equilibrium. Entrepreneurial processes are seen as carried out by the actions of business entrepreneurs profiting from temporary disequilibrium.

The notion of self-discovery was later used by Rodrik (2004) and Hausmann and Rodrik (2003) on a macro level when they wrote about national economic development. Selfdiscovery means to discover what economic activities can profitably be pursued in a given country, given the existing strengths and specialisations of the national economy. Selfdiscovery can benefit the whole economy, not just the firm that originally invested in the discovery, and accordingly, governments should implement economic policies that promote self-discovery.

The concept of smart specialisation was developed in the Knowledge for Growth group as a response to the economic crisis and growth problems in the EU (Foray, 2015). It quickly diffused into mainstream EU regional policy and has been used as an ex-ante condition for Structural Fund (SF) programmes since 2014 (Gianelle et al., 2016; Grillo, 2017). The strengths of the region (the 'self') should be found jointly in public-private alliances. Entrepreneurial discovery is the source of information on the new exploration and transformation activities which should be supported in Research and Innovation Strategies for Smart Specialisation (RIS3). The planners of RIS3 suggested a learning process to discover the business fields in which a region might hope to be competitive.

According to Radosevic (2017b), S3 applied in the EU is one approach to so-called new industrial policies which support diversification and technological upgrading. According to these policy approaches, the constraints of growth and new possible business fields are not known ex ante, and the design of the discovery process is important. Instead of an a priori defined policy target, search networks should be established to examine technological change and its effects (Radosevic, 2017b:7). Radosevic (2017b) includes among the new industrial policy approaches Rodrik's notion of self-discovery, diagnostic monitoring (Kuznetsov and Sabel, 2017) based on experimentalist governance, and the product space approach set out by Hausmann and Hidalgo (Hausmann et al., 2011; see Nguyen and Mariussen, 2019). In addition, approaches like new structural economics, neo-Schumpeterian and Schumpeterian perspectives emphasising targeting industries that constitute the country's latent comparative advantages can be included among the new industrial policies.

The shift of emphasis from individual to collective entrepreneurship has implications for the process of learning, and these are examined below. 


\section{The Austrian approach to microeconomics: The individual entrepreneur and discovery - Hayek and Kirzner}

The notion of discovery is central to the Austrian approach. Entrepreneurs drive the market process, and the entrepreneurial role offers a theoretical explanation for its ever-changing nature. Hayek $(1945 ; 1978)$ emphasised the nature of competition as a discovery procedure. He interpreted the market process as a process of mutual discovery, during which the market participants become better informed of the plans made by other participants. Some plans must prove to have been mistaken; they are seen as errors which tend to be overcome as market experience reveals that they are not viable when some other actions prove themselves profitable. Decision-makers might discover that a plan is not viable when a prior error in their view of the world is revealed, and they can then correct the view. Earlier plans might have overlooked existing profit opportunities, but such opportunities might be reflected in later plans. This example also offers a new insight into the nature of discovery: When people become aware of what they have overlooked previously, their view of the world will change. Discovering previously unknown profit opportunities is different from a successful search based on the deliberate production of information that was known to be missing. Discovery means that surprise comes with the realisation that something that was in fact available had been overlooked. Discoveries occur because human agents are alert (Kirzner, 1973), and the alertness expresses itself in the boldness and imagination. Alertness also means an attitude of responsiveness to available opportunities. The entrepreneurs search for unnoticed features of the environment that could inspire new activity and lead to discoveries.

Kirzner held that entrepreneurial discovery occurs because the price system does not always allocate resources effectively. People's views on the efficient use of resources are based on incomplete information. Their inaccurate decision-making framework can prompt people to make erroneous decisions, which in turn create shortages and surpluses. By responding to these shortages and surpluses, people can obtain resources, recombine them and sell the output in the hope of making a profit. The earlier errors create profit opportunities and tend to stimulate successive entrepreneurial discoveries, when market participants become aware on their errors and make more accurate decisions. Discovery drives pricing, and both output and input quantity and quality, towards values consistent with equilibrium (Kirzner, 1997). Changes in tastes and technology mean that complete equilibrium will never be achieved, even though there is a continuous process pursuing equilibrium.

Kirzner (1973) also stated that opportunities occur when people have differing views on existing information. This view differs from Schumpeter's (1934) perspective that entrepreneurial opportunities are changing and emerging due to the appearance of new information. The changes in technology, regulation, macroeconomic factors, and social trends create new information that entrepreneurs can use to recombine their resources into new forms (Shane, 2003:34). The creation of new forms of entrepreneurship and new trajectories might require the destruction of existing ones. This is called creative destruction. This idea of creative destruction is also at the core of the transformation of the regional economy through EDP.

\section{Self-discovery and new industrial policy - Rodrik \& Hausman}

While Austrian economists presented the view of entrepreneurs driving a discovery process in the market, Rodrik (2004) developed a macro level concept of self-discovery advocating firms 
and government explore the future together. Rodrik felt that firms have a knowledge deficit, especially when they are exploring new technologies and emergent markets, where neither costs nor clients are known in advance. Industrial policy should be a process of economic self-discovery (Hausmann and Rodrik, 2003) in which firms and governments learn about underlying costs and opportunities and engage in strategic coordination. Public action should encourage restructuring, diversification and technological dynamism beyond a level market forces would generate.

The idea of strategic cooperation between firms and governments in the EDP is based on Rodrik's (2004) ideas of self-discovery. Rodrik argued in favour of a proactive state and new industrial policy that sets vertical priorities: The state should support experimentation and explore and engage in a process of self-discovery with its industrial partners. The policy needs to allow for experimentation in order to discover what works and what does not in a particular context. Failures must also be noted in order to identify successes (Foray, 2015:39-49; Rodrik, 2004; 2007). Industrial policy should be an iterative process of economic selfdiscovery. Evaluation is a central policy task. Policymakers should design ex-ante procedures evaluating potentials and priorities as well as ex post procedures identifying success and failure. An exit provision for the supported activities after a certain period of time is central to a policy based on experimentation (Rodrik, 2004). However, it is difficult to assess the stability and sustainability of a specialisation at an early stage (Foray, 2015:51).

Public-sector officials should collate information from the business sector on constraints and possible opportunities. These ideas have much in common with the literature on institutional innovation and social learning (see e.g. Sabel and Zeitlin, 2010). According to Sabel and Zeitlin (2010) learning institutions must be experiment oriented, since discovery requires experimentation on the ways in which restructuring bottlenecks can be released, which necessitates a trial-and-error approach to policymaking (Rodrik, 2014).

The policy design of S3 is inspired by the new industrial policy school established by Rodrik and which has established the design principles of an industrial policy.

The design principles for industrial policy according to Rodrik (2004) and supported by Morgan (2017a) are:

1. Incentives should be provided only to support new activities.

2. There should be clear criteria for success and failure.

3. There must be a built-in sunset clause.

4. Public support must target activities not sectors.

5. Activities that are subsidised must have potential for providing spillovers.

6. Industrial policy should be driven by competent authorities.

7. Implementing agents should monitor.

8. The agencies carrying out promotion must maintain channels of communication with private-sector.

9. Mistakes will occur.

10. Promotion activities need to have the capacity to renew themselves so that the cycle of discovery becomes an ongoing one.

We can now see how Foray designed his collective actor. It was a move from national industrial policy to regional development strategies. 


\section{The entrepreneurial discovery process of the collective actor at the regional level-Foray}

Foray combined the ideas of entrepreneurial discovery (business studies) and self-discovery (Rodrik, Hausmann) and developed the regional theory in a unique and innovative way based on the notion of the EDP. While entrepreneurial discovery at the firm level equates to the exploration of opportunities, at the regional level it is a question of a process of a collective search for the future desirable business areas for a region. The aim is structural transformation via exploration of new business domains for the regional economy. The starting point of the search is a region's existing strengths, and the idea is to combine entrepreneurial and economic knowledge and discover a region's latent competitive advantage in the process of self-discovery.

The 'self' in EDP is a large set of public and private actors involved in the process of discovering which domains a region should move into so as to best construct its future. By opening and exploring new domains of opportunities, the process of entrepreneurial discovery is a central tool to solve the information problem that the government alone cannot solve. As such, it is characterised by a strong learning dimension (Foray, 2016).

The discovery may be about the potential of general purpose technologies (GPTs) to transform processes in the traditional sector, or it may be the possibility of a diversification path based on the exploitation of potential economies of scope and internal spillovers, or a transition path from a low-productivity area to a higher productivity one (Foray, 2015:23-24). A new regional capacity may be needed to initiate structural changes like diversification, transition, modernisation, or the radical foundation of industries and/or services (Foray, 2015:28-29).

The outcomes of the discovery are the key priorities of a region's smart specialisation strategy, which aims to build the capacity to implement and experiment with the desired domain. It consists of the support agenda for activities and capacities, for instance R\&D, which are needed to complement the region's productive assets to create future competitive advantages (Foray, 2015:5). They can be based on both local assets and extra-regional capabilities. The transformation of the productive structures and capacities requires new resources, new technologies and new competencies, which can be based on regional assets or extra-regional capabilities (Foray, 2015:1-2). When the resources are concentrated in the selected domains, new activities can be created enabling and facilitating the transformation and renewal of the regional economy. This renewal can form the basis for a unique regional competitive advantage which can be valuable, rare, inimitable and non-substitutable.

Based on the ideas of new industrial policy, Foray $(2015 ; 2016)$ points to the role of the vertical priorities and vertical policies needed to target activities aimed at exploring and experimenting and also learning what should be undertaken in the future. Foray also describes the EDP as combining these two somewhat conflicting principles: vertical priorities and decentralised entrepreneurial initiatives. Interventions should be based on vertical priorities but support the decentralised decisions of entrepreneurs on R\&D, innovation and structural changes.

RIS3 and EDP rely on the theories of experimental learning expounded by Sabel (1993). Experimentation means that mistakes will be made, and failure will be experienced, something sometimes necessary in the discovery process. The aim is not to reduce the risk of 
error but to minimise its cost. RIS3 processes aim to incorporate trial-and-error mechanisms into their programmes (Morgan, 2017b). The indicators and evaluations are important (McCann and Ortega-Argilés, 2013) and ex-ante criteria to assess projects or domains and select priorities and to determine exit provisions after a certain period of time are important mechanisms of a continuous process of discovery and are thus drivers of regional economic growth (Foray, 2015:39; Rodrik, 2004; 2007).

The collective entrepreneurial actor capable of performing of self-discovery encounters the problem of knowledge fragmentation, which the individual entrepreneur can choose to disregard by selecting a scope suitable for its own benefit rather than the region's.

\section{Entrepreneurial actors building a collective regional agent}

A collective regional agent is a necessary element of the EDP because the entrepreneurial knowledge about opportunities, constraints, and challenges (Foray, 2016) is dispersed and embodied in and possessed by entrepreneurial actors. Single entrepreneurial actors have their own experience and the entrepreneurial knowledge possessed by any single actor is narrow in scope. This knowledge is valuable, but it should be positioned in relation to entrepreneurial knowledge collected from other sources in the discovery of the new domain (Rodríguez-Pose and Wilkie, 2017; Foray, 2015:25).

This creates a challenge. Entrepreneurial knowledge involved in EDP is not available in a compact form in one location (or entity), and part of the relevant knowledge might reside outside of the region (Foray, 2015:34-35). According to the RIS3 guide (Foray et al., 2012) and the handbook of implementation (Gianelle et al., 2016) the challenge can be resolved by forming as broad and inclusive a partnership as possible, involving a wide variety of stakeholders within local societies. Firms are central since they are engaged with the market, they have entrepreneurial knowledge, and they can explore and test new ideas and implement innovations that can trigger the transformation of the regional economy. In addition to firms, the relevant entrepreneurial actors might also be higher education institutes, public research institutes, independent innovators, and other actors able to discover the new domains of R\&D and innovation triggering structural change in the regional economy (Foray et al., 2012:12). All sources of entrepreneurial knowledge are necessary and complementary.

However, many authors have underlined the difficulties in this broad inclusion. McCann and Ortega-Argilés (2013) and Morgan (2017b) have argued that such a shift requires transparency in order to ensure public accountability. Moreover, regional entrepreneurial actors might have rent-seeking and vested interests resulting in lock-in; a situation that can give rise to a wicked game played among the actors (see Mäenpää and Lundström, 2019). One option to avoid local rent-seeking behaviour and lock-in is to involve non-local actors in the EDP, as well as new players possibly alongside established players. However, those established players with their vested interests should commit to contribute to the development of new specialisations in the region (Boschma, 2017).

EDP is an open and gradually changing process, and a new actor can join during the process. A collective of regional entrepreneurial actors can be seen as a form of regional development network with a specific focus, namely entrepreneurial discovery. The collective regional actor should have a transformative capacity, the ability to reflect the given rules and norms, and 
also be capable of creating new institutions, which implies it has features typical of an institutional entrepreneur (Sotarauta and Pulkkinen, 2011).

It is important to specify clearly how the collective entrepreneurial actor in a regional process of discovery can come into being, and accordingly the following paragraphs introduce the triple helix.

\section{Triple-helix actors and governance}

The triple-helix (TH) model (Leydesdorff and Etzkowitz, 1998; Etzkowitz and Leydesdorff, 2000) is used to describe both dynamic interaction between universities, companies and public institutions and institutional continuity, as these helices consist of historical institutions with selection environments or rules. Universities, as scientific systems, communicate and function in accordance with the code of true/false, companies in accordance with the code of profit/loss, and the public sector in accordance with the code of right/wrong. The concept of $\mathrm{TH}$ has been applied in smart specialisation to form the basis for connectivity within regions. TH actors (i.e. Universities, companies, and public organisations) are expected to be at the forefront of the EDP and they should work along the same lines (Virkkala et al., 2017). Finne and Aasen (2019) examine the role of universities in the transformation of regional economies and EDP, with particular emphasis on how they can contribute to the conversion and not just transfer of knowledge to entrepreneurial actors.

A connected region is a norm or vision where the three helices work in harmony and mutually reinforce each other (Goddard et al., 2013). They co-evolve and interact through an overlay of recursive networks and organisations, which can be seen as a precondition for innovation. In a disconnected region, there are no boundary spanners, the partnerships are ineffective or nonexistent, and there is a lack of understanding of the changes. Entrepreneurs are locked out of regional planning (Goddard et al., 2013) and no EDP can emerge. In other words, TH connectivity supporting successful implementation of RIS3 should include an option for entrepreneurs to participate in its planning processes. TH actors should be connected in the search for new growth potential. Better cooperation creates more opportunities for innovative interaction, which can expand the intersection between helices and form a point of departure for additional EDPs (Virkkala et al., 2017).

In the exploitation phase there is a division of specialised labour between different actors and institutions (universities, companies, public agencies, etc.) optimising productivity. But what is productive and necessary in exploitation is fragmented when the focus shifts to exploration. In that case, the public sector acquires a new role.

\section{The role of the public sector in the EDP}

The policy design, implementation and evaluation of S3 is challenging and requires the governments involved to have strong competencies. Regional governments are obliged to take the initiative in the process, but they also participate in the discovery process that is based on the interaction between entrepreneurial actors in the broad sense. Although entrepreneurs are the key actors in the discovery, the interactive strategic cooperation should be organised and coordinated by public governments. 
Creation of a public-private alliance for discovery is a challenging task for a public organisation. This alliance might be created by design, but it is suggested here that the formation process of this alliance can be compared with the emerging community of practice described by Wenger (1998). We apply the concepts of engagement, alignment, and imagination used in the theory of community of practice when describing the challenges of organising entrepreneurial discovery. The first challenge is engagement: the identification and mobilisation of all relevant entrepreneurial actors. Entrepreneurial actors are all stakeholders and individuals who hold knowledge relevant to the discovery process. All relevant stakeholders can be invited, and there should be sufficient variety of voices engaged in building the future opportunities for the region. The government or the facilitator should build connections between the partners. Some of the relationships in the alliance might be strong, but most ties are weak.

The second challenge is to create alignment (cohesion) among the diverse entrepreneurial actors, and a trusting atmosphere is essential to generate a common vision. Entrepreneurial actors might have conflicting interests and strategies. They might have vested interests and perhaps no interest at all in regional affairs; they might strive to further their interests; and there is a risk of a lock-in situation. The facilitator should aim to build a common mode of interpretation and common interest in the discovery of new business areas. One possibility is to aim for a dual-reference frame, which is marked by the actors establishing the region as a frame of reference for their thinking and their decisions, alongside an already existing frame of reference. This can be achieved through structured dialogue on the future of region's economy in which the actors might put the aims and issues not shared by others to one side and think in terms of which aspects are shared by the regional actors. Dualism in the reference frame and the ability to manage that dualism is a key characteristic of the individual leadership required for territorial strategy-making (Aranguren et al., 2017). Dual leadership is especially difficult in less-developed regions with low levels of trust (see Blažek and Morgan (2019), Chapter 3 in this volume, for an outline design of an inclusive EDP in less-developed regions). The community of practice theory focuses on different borders and challenges between the entrepreneurial actors representing different communities of practice. This might hinder the interaction between agents, and translation of the practices will be necessary for knowledge conversion (see Lam, 2019).

Alignment means that the proximities of the entrepreneurial actors change and new knowledge space will be created. New relations might emerge, and the previously proximate relationships might become more distant, see Chapter 8 (Virkkala, 2019).

Imagination facilitates orientation with the help of analogies and visual representations, symbolic expressions, reflection, scenarios and experimentation. In the context of the EDP, there might be a growing understanding of the opportunities for and limitations to the region's growth which will be discovered through the process (Radosevic, 2017b).

The collectively constructed new opportunities will be captured in the smart specialisation policy. The policy priorities should be identified in an interactive process that generates detailed information about new activities. Afterwards, the regional government assesses the activities' potential and empowers those actors most capable of realising that potential. The government is not neutral in this process but instead selects the relevant vertical priorities. This can be seen as a process of creating disequilibrium instead of equilibrium. Public-sector agencies have a central role in implementing RIS3 and selecting projects supporting the early growth of the new business field. They should create incentives to support risky projects 
exploring a new domain of opportunities in a way that maximises knowledge spillovers from the projects (Foray, 2017).

There can be also shared leadership in the EDP. Government agencies are likely to have the capacity to undertake the leadership role required for process design and to create the optimal conditions to foster the engagement of relevant stakeholders (Aranguren et al., 2017). The appropriate knowledge leadership is more likely to be found in technology centres, universities, leading firms or business clusters. Regional technology organisations (RTOs) (Charles and Ciampi Stancova, 2017) are often able to identify industry needs and technological opportunities, and can collect information on international markets, intermediate in the process and translate the global knowledge for regional firms through their networks. They can play a central role in integrating the relevant entrepreneurial knowledge distributed through entrepreneurial actors. Moreover, they can support the exploration of new opportunities by organising platforms and seminars (Charles and Ciampi Stancova, 2017).

\section{Smart specialisation in relation to other regional development policy theories}

Many of the routines, practices and tools necessary for the implementation of RIS3 have already been discussed in economic geography and related research (Kroll, 2015). The discussion includes concepts such as constructed advantage (Asheim et al., 2011), endogenous approaches (Tödtling, 2011), triple-helix connected regions (Goddard et al., 2013), place-based development (Barca et al., 2012), and the process of discovery and general purpose technologies (Foray et al., 2009). Smart specialisation can therefore be seen as the synthesis of different frameworks and approaches. However, it differs from the earlier theories since it has been formulated as a clear theory and practice driven policy by Foray (2015) and others.

The RIS3 is based on the legacy of regional innovation system (RIS) thinking that has been used in regional economic development policy over the past 25 years (Asheim and Gertler, 2005; Cooke et al., 2004). It also draws on the experience gained from previous EU initiatives promoting the development of regional innovation strategies. Doloreux and Porto Gomez (2017) point out that RIS research has explored how regions generate the conditions capable of boosting innovation, and especially how regional dynamics can foster firm-level innovation, but it has not systematically explored the benefits of innovation at the regional level. The RIS literature often assumes that the conditions contributing to innovation will automatically lead to growth, and there is little RIS research on the way local innovation is associated with regional economic growth and the transformation and mutations of RISs. Smart specialisation is one response to the problems of RIS research.

Table 1.2 compares the ideas of cluster theories, innovation system theories and smart specialisation or EDP theories. The focus of the theories differs: cluster theories explain how clusters are emerging and developing, RIS theories explain how innovations are emerging in the interaction of knowledge producers and knowledge users. Isaksen et al. (2019) use the RIS approach to distinguish between different regional institutional contexts affecting the EDP. Smart specialisation focuses on exploration and explains how to create new domains for business opportunities. The cluster approach is based on firms in specific sectors and the firms related to them. In that context, the lead firms are the main actors whereas in both the innovation system approach and smart specialisation, the focus might be on companies, public 
and private organisations, universities and third-sector organisations. However, while RIS theory emphasises the division of labour between knowledge producers and knowledge users, according to the smart specialisation approach, the public-private alliances collectively search for new domains. Government is the main facilitator in both the RIS and smart specialisation approaches whereas, as mentioned above, cluster theories focus on the role of the lead firms.

Cluster theory tend to rely on knowledge embedded in a relevant, and accordingly restricted set of sectors. Both RIS and smart specialisation approaches recognise that knowledge is distributed among many actors, any of which can contribute to innovation processes and entrepreneurial discovery. Smart specialisation is related more directly to generating regional growth by recombining existing knowledge and capabilities in a new way to form crosssectoral domains. This occurs with R\& D investments, embeddedness and connectivity through the process of self-discovery. The cluster approach highlights the localisation advantages of a specialised labour market, specialised knowledge circulation and spillovers, and common services. The RIS approach can have urbanisation advantages, but the idea of the EDP is to transform the regional economy. Smart specialisation aims to mobilise the firms and other relevant actors and is characterised by a more bottom-up approach than the cluster and RIS approaches.

Both the role of public-sector actors and the objectives of the policies differ between the three approaches. While the cluster policy takes a neutral stance on supplying education and infrastructure, the RIS policy aims to establish better governance of the innovation system and stronger connectivity between the subsystems to generate more innovations, whereas the smart specialisation policy is non-neutral, prioritising the activities of a new domain with the potential to transform the regional economy. Smart specialisation policy also recognises the possibility of failure and encourages experimentation.

The three approaches also have similarities. They all emphasise place-based development to some extent. Cluster policy and RIS policies are place-based development policies in the sense that the clusters and innovation systems are based on regional networks. However, place-based development is even more essential in smart specialisation; it is an integrated place-based economic transformation agenda that is built on each region's strengths and that focuses policy on key regional priorities. The place-based approach is based on the idea of endogenous development that entails regions identifying, developing and utilising their unique resources. The place-based approach to development dictates that the RIS3s should be tailored to the local context (McCann and Ortega-Argilés, 2013). S3 begins with the region's strengths, clusters thrive on those strengths of the region that are to their benefit.

The three concepts align and interact. A RIS can be established when emerging clusters are promoted by the knowledge generation bodies, and transfer and support organisations are established. RIS can consist of many clusters. RIS theory has informed smart specialisation, and S3 can be seen as a continuation of RIS policies in a new form. The discovery of new business areas may lead to clusters and cluster policies. However, the added value of smart specialisation and EDP compared to cluster and system of innovation policies is a move in the direction of exploration and economic growth, rather than of the facilitation of general frameworks supporting innovation.

Table 1.2 Cluster, innovation system, and smart specialisation (EDP) 


\begin{tabular}{|c|c|c|c|}
\hline & Cluster & Innovation system & Smart specialisation \\
\hline Scope & $\begin{array}{l}\text { Specific sector and } \\
\text { related activities }\end{array}$ & Regional platforms & $\begin{array}{l}\text { Domains for business } \\
\text { opportunities }\end{array}$ \\
\hline Actors & $\begin{array}{l}\text { Firms within certain } \\
\text { industry and related } \\
\text { fields }\end{array}$ & $\begin{array}{l}\text { Firms, public and private } \\
\text { organisations, NGOs }\end{array}$ & $\begin{array}{l}\text { Firms, public and private } \\
\text { organisations, NGOs, citizens }\end{array}$ \\
\hline Process, activity & Cluster life cycle & Innovation & Self-discovery \\
\hline $\begin{array}{l}\text { Knowledge and } \\
\text { innovation }\end{array}$ & $\begin{array}{l}\text { Specialised } \\
\text { knowledge, local } \\
\text { knowledge spillovers }\end{array}$ & $\begin{array}{l}\text { Regional knowledge } \\
\text { spillovers, innovations as } \\
\text { social processes }\end{array}$ & $\begin{array}{l}\text { Entrepreneurial knowledge } \\
\text { combined with general } \\
\text { purpose technologies }\end{array}$ \\
\hline $\begin{array}{l}\text { Dynamic/driving } \\
\text { forces }\end{array}$ & $\begin{array}{l}\text { Localisation } \\
\text { advantages }\end{array}$ & $\begin{array}{l}\text { Urbanisation economies, } \\
\text { related variety }\end{array}$ & $\begin{array}{l}\text { Entrepreneurial discovery, } \\
\text { diversification; } \\
\text { transformation of the regional } \\
\text { economy } \\
\text { New domains; knowledge } \\
\text { spillovers; entry of firms; } \\
\text { agglomeration }\end{array}$ \\
\hline Competitors & $\begin{array}{l}\text { Clusters of the same } \\
\text { industrial sectors }\end{array}$ & $\begin{array}{l}\text { Other innovation systems } \\
\text { attracting knowledge flows; } \\
\text { labour force and } \\
\text { investments }\end{array}$ & $\begin{array}{l}\text { Other regions of specialised } \\
\text { fields attracting knowledge } \\
\text { flows; labour force and } \\
\text { investments }\end{array}$ \\
\hline Governance & Top down & Top down & Top down $\&$ bottom up \\
\hline Public sector role & $\begin{array}{l}\text { Education, training, } \\
\text { infrastructure }\end{array}$ & $\begin{array}{l}\text { Innovation system } \\
\text { governance; intermediation; } \\
\text { education; training; } \\
\text { infrastructure }\end{array}$ & $\begin{array}{l}\text { Initiating and managing of the } \\
\text { strategy process; financer; } \\
\text { cooperation partner }\end{array}$ \\
\hline $\begin{array}{l}\text { Objective of the } \\
\text { policy }\end{array}$ & $\begin{array}{l}\text { Speeding the growth } \\
\text { of local clusters and } \\
\text { improvement of } \\
\text { competitiveness }\end{array}$ & $\begin{array}{l}\text { Stronger connectivity } \\
\text { between different } \\
\text { subsystems (research and } \\
\text { industry) }\end{array}$ & $\begin{array}{l}\text { Discovery of areas of new } \\
\text { domains that are difficult to } \\
\text { imitate; prioritisation; } \\
\text { supporting implementation; } \\
\text { experimentation }\end{array}$ \\
\hline $\begin{array}{l}\text { Most important } \\
\text { policy challenge }\end{array}$ & $\begin{array}{l}\text { Renewal of old } \\
\text { declining industrial } \\
\text { clusters }\end{array}$ & $\begin{array}{l}\text { Creation of structures } \\
\text { supporting innovation } \\
\text { processes, promoting } \\
\text { knowledge flows and } \\
\text { learning }\end{array}$ & $\begin{array}{l}\text { Changes in behaviour of firms } \\
\text { and public government }\end{array}$ \\
\hline
\end{tabular}

Source: Modified from Rinkinen and Harmaakorpi (2017), Foray (2015), Doloreux and Porto Gomez (2017)

\section{Critical reflections on EDP and smart specialisation}

The rapid move from a conceptual idea to mainstream EU policy (Kroll, 2015) has led to criticism of the theories of smart specialisation and EDP as policy models and the implementation of smart specialisation strategies in the EU. Scholars have criticised the theory approach of EDP and smart specialisation especially in terms of the use of regions and regional typologies. Camagni and Capello (2013) point out that space can be more diversified. Less developed regions often have unfavourable research and innovation systems and are typically dealing with organisational thinness, a state of lock-in to declining sectors and outdated technologies, fragmented systems that inhibit networking and knowledge exchange, and a weak capacity to drive transformative change (Healy, 2016; Blažek and Morgan, 2019). Cooke (2012:216-220) criticises smart specialisation for its apparent overemphasis on science and technology-led innovation with a focus on high-tech sectors, and Capello and Lenzi (2013) do the same for its focus on imitative innovation. Furthermore, Morgan $(2015 ; 2017 \mathrm{~b})$ 
states that the concept of smart specialisation should take greater account of the role of social innovation and the innovation found within the public sector. The public sector can be a repository of entrepreneurial knowledge and be the main driver in the discovery process. Benner (2017) criticises the S3 for focusing more on macro-level collaboration of stakeholders and collective policymaking than micro-level dynamics leading to smart experimentation. However, micro-level dynamics can be included in a continuous EDP (Foray, 2016), and the loops between different levels (see Chapter 9 by Virkkala and Mariussen (2019) on emergence).

Estensoro and Larrea (2016) argue that political habits, practice, and routines (the policymaking modes) are of substantial importance for the degree of efficacy and efficiency with which RIS3 can be implemented. The smart specialisation approach requires a serious reflection on a region's assets, capabilities and weaknesses. Regional innovation paths depend on deep-rooted territorial elements such as history, culture, and learning processes (see Blažek and Morgan, 2019). In addition, RIS3 can be seen as a wicked game played by the different regional, national, and international actors in which some actors define the rules (see Mäenpää and Lundström, 2019).

Many scholars have been critical of the implementation of S3. According to Marques and Morgan (2018), S3 is based on many implicit heroic assumptions that might limit its impact, especially in less-developed regions with low institutional capacity. It places enormous demands on the stakeholders involved in it, especially the public-sector organisations with the key role in the programme design. The state is supposed to be smart enough, but it is often not flexible and ready to adopt experimentation. A triple-helix coalition is assumed to be in place, but in reality, the partners may not be cooperating. Radosevic (2017a) concludes case studies on the implementation of S3 by remarking that the experimental nature of the EDP is repressed by political and administrative requirements. The practices of the European Commission and regions are difficult to adapt to those required by the EDP. Even if the initial selection processes have applied experimentation, implementation is often run as a conventional public funding programme.

The EDP and smart specialisation are arguably unique and creative concepts in that they combine the development of a regional economy with policies, and also regional priority setting with the idea of market processes. EDP theory addresses the criticism of RIS since the starting point is regional economic growth and the search for growth areas in which innovations could emergence. In this way EDP theory opens the black box between innovation and growth that RIS fails to.

However, some of the criticism of the EDP is compelling, especially as regards the role of formal and informal institutions and the different contexts to the EDP and its performance. In spite of this criticism we would like to emphasise the advantages of having a common policy approach, because it provides for a common framework for transnational learning (Mariussen and Virkkala, 2013). Some of the policy-related features are similar across regions whereas others are unique to specific regions (McCann and Ortega-Argilés, 2017). The smart specialisation agenda includes advanced knowledge sharing on regional innovation and development policies in the EU with the help of the S3 platform to enable policy learning (Kroll, 2015). Chapter 11 (Mariussen et al., 2019) documents how the smart specialisation platform aims to help regions and Member States to prioritise and align efforts between public and private stakeholders. 
We also suggest some new challenges. The first one is to transform the static structure into a more complex and dynamic process by moving the attention from the micro level to the macro level. This process is necessary for the transformation of the regional economy and will be discussed with reference to complexity perspectives in Chapter 7 by Aasen (2019) and Chapter 9 by Virkkala and Mariussen (2019).

The second challenge is related to the concept of knowledge used in the EDP. Foray (2015) does not discuss sufficiently the role of tacit knowledge and knowledge conversion in entrepreneurial discoveries. Foray asserts that entrepreneurial knowledge is an aggregate of the knowledge possessed by different entrepreneurial actors; however, knowledge is not only aggregate, it should also be processed, combined with other knowledge and absorbed and assimilated so it may be used as an outcome of the EDP. This knowledge creation, conversion, and translation process is an interaction process between tacit and codified knowledge, and individuals and organisations. This book seeks to broaden the concept of entrepreneurial knowledge and discovery by placing the EDP in the framework of organisational knowledge creation theories. All knowledge depends on preconceptions, and the knowledge process can be seen as a process of sense-making. The knowledge process will be discussed further in Chapters 5, 7, and 8 (by Lam; Aasen; Virkkala (2019), respectively), and illustrated in several case chapters.

The third challenge is to combine the strengths of place-based development with emerging European level thematic partnerships. This means enlarging the field of self-discovery from regional-level entrepreneurial actors to the European level. The entrepreneurial actors of different regions will collaborate in broader transnational and macro-regional strategic frameworks. As the EDP is transforming a regional economy and strengthening the RIS, the newly discovered regional domains can be extended by opening the economy and connecting it to macro-regional and European knowledge networks and systems of innovation. In this way, the regional economy can grow as a part of a larger, stronger and more dynamic innovation system, and also be integrated into the European economy. This challenge is discussed in Chapter 11 by Mariussen et al. (2019).

\section{Conclusion}

The rapid translation into practice of theoretical ideas that are still in development sets challenges for implementation. However, the translation process might also provide an opportunity to develop theory in practice rather than as a linear leap from theory to practice without 'proof of concept' (Nauwelaers et al., 2015:3).

The current chapter has examined self-discovery as a process enabling EDP and the transition between knowledge exploitation and exploration. It examined the requirements of the regional actors involved in the EDP. It revealed the journey of the concepts of self and discovery from one of individual entrepreneurs discovering business opportunities owing to their alertness and incomplete information as proposed by Hayek and Kirzner to one based on the theory of self-discovery by Rodrik in the context of a national economy. Foray (2015) combined the notion of entrepreneurial discovery, the notion of self-discovery from new industrial policy from Rodrik, the ideas of experimentalist governance from Sabel, and the place-based strategies of Barca (2009) in the concept of the EDP. The EDP is a collective search of entrepreneurial actors (i.e. quadruple helix actors) for new future growth opportunities to support the development of regions (Table 1.3). It involves the discovery of the business 
fields on which a region should construct its future in the knowledge economy. The EDP means a transition from the exploitation to the exploration of knowledge or to the creation of new knowledge. EDP is a move from a state of knowledge and division of labour between actors, as in knowledge exploitation progressing towards exploration through a process of self-discovery, a new cognitive understanding of a region's opportunities, and the integration and translation of fragmented knowledge. The EDP can occur spontaneously in a decentralised way without any support. The entrepreneurs have a vision, and the discovery of a new domain and the integration of different types of knowledge can make that vision a reality. Nevertheless, policy support is often necessary, and the EDP is the core method in the European cohesion policy. Some of the features of smart specialisation were practised implicitly by regional development policies searching for continuous renewal even before its official launch in 2014 as a cornerstone of EU cohesion policy.

Table 1.3 Development of the concepts of 'discovery' and 'self'

\begin{tabular}{|c|c|c|c|c|c|}
\hline & Discovery & Self & Level, context & Aim & Policy \\
\hline Kirzner (1997) & $\begin{array}{l}\text { Discovery of } \\
\text { previously } \\
\text { unknown profit } \\
\text { opportunities }\end{array}$ & $\begin{array}{l}\text { Individual } \\
\text { entrepreneur }\end{array}$ & $\begin{array}{l}\text { Market } \\
\text { economy }\end{array}$ & $\begin{array}{l}\text { Towards market } \\
\text { balance with } \\
\text { more } \\
\text { information }\end{array}$ & Laissez-faire \\
\hline $\begin{array}{l}\text { Hausmann and } \\
\text { Rodrik (2003) }\end{array}$ & $\begin{array}{l}\text { Economic Self- } \\
\text { discovery of } \\
\text { latent } \\
\text { competitive } \\
\text { advantage }\end{array}$ & $\begin{array}{l}\text { Firms and } \\
\text { government } \\
\text { together }\end{array}$ & $\begin{array}{l}\text { National } \\
\text { economy, } \\
\text { development } \\
\text { countries }\end{array}$ & $\begin{array}{l}\text { Restructuring, } \\
\text { beyond market } \\
\text { forces; iterative } \\
\text { process }\end{array}$ & $\begin{array}{l}\text { New industrial } \\
\text { policy: } \\
\text { diversification; } \\
\text { experimentation; } \\
\text { non-neutral }\end{array}$ \\
\hline Foray (2015) & $\begin{array}{l}\text { Self-discovery } \\
\text { of latent } \\
\text { competitive } \\
\text { advantage EDP }\end{array}$ & $\begin{array}{l}\text { Entrepreneurial } \\
\text { actors: firms, } \\
\text { public } \\
\text { government, } \\
\text { universities, } \\
\text { civil society }\end{array}$ & $\begin{array}{l}\text { Regions in } \\
\text { knowledge } \\
\text { economies; } \\
\text { place-based } \\
\text { development }\end{array}$ & $\begin{array}{l}\text { Transformation } \\
\text { of the regional } \\
\text { economy }\end{array}$ & $\begin{array}{l}\text { EU cohesion } \\
\text { policy; regional } \\
\text { innovation } \\
\text { policy }\end{array}$ \\
\hline
\end{tabular}

Source: Authors' interpretation of Kirzner (1997), Hausmann and Rodrik (2003) and Foray (2015)

The chapter compared the EDP and smart specialisation as a policy approach with the cluster theories and innovation system approaches. Cluster theories explain cluster life-cycles; RIS theories explain how innovation emerges in interaction between actors; and smart specialisation clarifies how to create new business opportunities and transform a regional economy. Cluster policy promotes the development of clusters through education and infrastructure, RIS policy supports the governance of an innovation system with stronger connectivity between actors. S3 focuses on mobilising actors and aims to push the regional economy in the direction of exploration and economic growth. However, S3 and the EDP have been criticised for their too demanding assumptions, for placing too much emphasis on science and technology led innovations, and for placing too little focus on institutional capacities.

\section{References}

Aasen, T. M. (2019). Approaching knowledge conversion in entrepreneurial discovery processes from a complex process theory perspective. In Mariussen, $\AA$., Virkkala, S., Finne, H. and Aasen, T. M. (eds.) The entrepreneurial discovery process and regional development: New knowledge emergence, conversion and exploitation. Abingdon: Routledge. 
Aranguren, M. J., Navarro, M. and Wilson, J. R. (2017). From plan to process: Exploring the human element in smart specialisation governance. In McCann, P., Goddard, J. and van Oort, F. (eds.) The empirical and institutional dimensions of smart specialisation, pp. 165-191. London: Routledge.

Asheim, B. T., Boschma, R. and Cooke, P. (2011). Constructing regional advantage: Platform policies based on related variety and differentiated knowledge bases. Regional Studies, 45 (7), pp. 893 904.

Asheim, B. T. and Gertler, M. S. (2005). The geography of innovation: Regional innovation systems. In Fagerberg, J., Mowery, D. C. and Nelson, R. R. (eds.) The Oxford handbook of innovation, pp. 291-317. Oxford: Oxford University Press.

Barca, F. (2009). An agenda for a reformed cohesion policy. A place-based approach to meeting European Union challenges and expectations. Occasional report. Brussels: European Commission.

Barca, F., McCann, P. and Rodríguez-Pose, A. (2012). The case for regional development intervention: Place-based versus place-neutral approaches. Journal of Regional Science, 52 (1), pp. 134-152.

Benner, M. (2017). Smart specialisation and cluster emergence: Elements of evolutionary regional policies. In Fornahl, D. and Hassink, R. (eds.) The life cycle of clusters. A policy perspective, pp. 151-172. Cheltenham: Edward Elgar.

Blažek, J. and Morgan, K. (2019). The institutional worlds of entrepreneurial discovery: Finding a place for less developed regions. In Mariussen, Å., Virkkala, S., Finne, H. and Aasen, T. M. (eds.) The entrepreneurial discovery process and regional development: New knowledge emergence, conversion and exploitation. Abingdon: Routledge.

Boschma, R. (2017). Regional diversification and smart specialisation policy. In McCann, P., van Oort, F. and Goddard, J. (eds.) The empirical and institutional dimensions of smart specialisation, pp. 23-38. London: Routledge.

Camagni, R. and Capello, R. (2013). Regional innovation patterns and the EU regional policy reform: Toward smart innovation policies. Growth and Change, 44 (2), pp. 355-389.

Capello, R. and Lenzi, C. (2013). Territorial patterns of innovation and economic growth in European regions. Growth and Change, 44 (2), pp. 195-227.

Charles, D. and Ciampi Stancova, K. (2017). Entrepreneurial discovery process and research and technology organisaitons. In Kyriakou, D., Martínez, M. P., Periáñez-Forte, I. and Rainoldi, A. (eds.) Governing smart specialisation, pp. 80-94. London: Routledge.

Cooke, P. (2012). Complex adaptive innovation systems. Relatedness and transversality in the evolving region. Milton Park: Routledge.

Cooke, P., Heidenreich, M. and Braczyk, H.-J. (eds.) (2004). Regional innovation systems. The role of governance in a globalized world, 2nd ed. London: Routledge.

Doloreux, D. and Porto Gomez, I. (2017). A review of (almost) 20 years of regional innovation systems research. European Planning Studies, 25 (3), pp. 371-387.

EC-JRC (2017). Entrepreneurial discovery process - EDP. Sevilla: European Commission. Available: http://s3platform.jrc.ec.europa.eu/entrepreneurial-discovery-edp [Accessed 2018-06-16].

Estensoro, M. and Larrea, M. (2016). Overcoming policy making problems in smart specialization strategies: engaging subregional governments. European Planning Studies, 24 (7), pp. 13191335 .

Etzkowitz, H. and Leydesdorff, L. (2000). The dynamics of innovation: from national systems and "Mode 2" to a triple helix of university-industry-government relations. Research Policy, 29 (2), pp. 109-123.

Finne, H. and Aasen, T. M. (2019). Universities that bridge and bond. In Mariussen, Å., Virkkala, S., Finne, H. and Aasen, T. M. (eds.) The entrepreneurial discovery process and regional development: New knowledge emergence, conversion and exploitation. Abingdon: Routledge.

Foray, D. (2015). Smart specialisation. Opportunities and challenges for regional innovation policy. London: Routledge.

Foray, D. (2016). On the policy space of smart specialization strategies. European Planning Studies, 24 (8), pp. 1428-1437. 
Foray, D. (2017). The economic fundamentals of smart specialization strategies. In Radosevic, S., Curaj, A., Gheorghiu, R., Andreescu, L. and Wade, I. (eds.) Advances in the theory and practice of smart specialization, pp. 38-50. London: Academic Press.

Foray, D., David, P. A. and Hall, B. H. (2009). Smart specialisation - the concept. Knowledge Economists Policy Brief. Brussels: European Commission.

Foray, D., Goddard, J., Goenaga Beldarrain, X., Landabaso, M., McCann, P., Morgan, K., Nauwelaers, C. and Ortega-Argilés, R. (2012). Guide to research and innovation strategies for smart specialisation (RIS 3). Occasional report. [Sevilla]: European Commission.

Gianelle, C., Kyriakou, D., Cohen, C. and Przeor, M. (eds.) (2016). Implementing smart specialisation: A handbook. Brussels: European Commission.

Goddard, J., Kempton, L. and Vallance, P. (2013). Universities and smart specialisation: challenges, tensions and opportunities for the innovation strategies of European regions. Ekonomiaz, (83), pp. 82-101.

Grillo, F. (2017). Structuring the entrepreneurial discovery process to promote private-public sector engagement. In Kyriakou, D., Martínez, M. P., Periáñez-Forte, I. and Rainoldi, A. (eds.) Governing smart specialisation, pp. 62-79. London; New York: Routledge.

Hausmann, R., Hidalgo, C. A., Bustos, S., Coscia, M., Chung, S., Jimenez, J., Simoes, A. and Y1ldırım, M. A. (2011). The atlas of economic complexity: Mapping paths to prosperity. Cambridge MA: Harvard University, Center for International Development.

Hausmann, R. and Rodrik, D. (2003). Economic development as self-discovery. Journal of Development Economics, 72 (2), pp. 603-633.

Hayek, F. A. v. (1945). The use of knowledge in society. The American Economic Review, 35 (4), pp. 519-530.

Hayek, F. A. v. (1978). Competition as a discovery procedure. In Hayek, F. A. v. (ed.) New studies in philosophy, politics, economics, and the history of ideas, pp. 179-190. Chicago: University of Chicago Press.

Healy, A. (2016). Smart specialization in a centralized state: strengthening the regional contribution in North East Romania. European Planning Studies, 24 (8), pp. 1527-1543.

Isaksen, A., Kyllingstad, N., Rypestøl, J. O. and Schulze-Krogh, A. C. (2019). Entrepreneurial discovery processes in different regional contexts. A conceptual discussion. In Mariussen, $\AA$., Virkkala, S., Finne, H. and Aasen, T. M. (eds.) The entrepreneurial discovery process and regional development: New knowledge emergence, conversion and exploitation. Abingdon: Routledge.

Kirzner, I. M. (1973). Competition and entrepreneurship. Chicago; London: University of Chicago Press.

Kirzner, I. M. (1997). Entrepreneurial discovery and the competitive market process: An Austrian approach. Journal of Economic Literature, 35 (1), pp. 60-85.

Kroll, H. (2015). Efforts to implement smart specialization in practice-Leading unlike horses to the water. European Planning Studies, 23 (10), pp. 2079-2098.

Kuznetsov, Y. and Sabel, C. (2017). Managing self-discovery: Diagnostic monitoring of a portfolio of projects and programs. In Radosevic, S., Curaj, A., Gheorghiu, R., Andreescu, L. and Wade, I. (eds.) Advances in the theory and practice of smart specialization, pp. 51-72. London: Academic Press.

Lam, A. (2019). Career mobility, hybridity and knowledge combination: A 'third space' perspective. In Mariussen, Å., Virkkala, S., Finne, H. and Aasen, T. M. (eds.) The entrepreneurial discovery process and regional development: New knowledge emergence, conversion and exploitation. Abingdon: Routledge.

Leydesdorff, L. and Etzkowitz, H. (1998). The Triple Helix as a model for innovation studies. Science and Public Policy, 25 (3), pp. 195-203.

March, J. G. (1991). Exploration and exploitation in organizational learning. Organization Science, 2 (1), pp. 71-87.

Mariussen, Å. and Virkkala, S. (eds.) (2013). Learning transnational learning. Abingdon: Routledge.

Mariussen, Å, Hegyi, F. B. and Rakhmatullin, R. (2019) Smart specialisation: Interregional learning via thematic partnerships. In Mariussen, Å., Virkkala, S., Finne, H. and Aasen, T. M. (eds.) 
The entrepreneurial discovery process and regional development: New knowledge emergence, conversion and exploitation. Abingdon: Routledge.

Marques, P. and Morgan, K. (2018). The heroic assumptions of smart specialisation: A sympathetic critique of regional innovation policy. In Isaksen, A., Martin, R. and Trippl, M. (eds.) New avenues for regional innovation systems - theoretical advances, empirical cases and policy lessons, pp. 275-293. Cham: Springer International Publishing.

McCann, P. and Ortega-Argilés, R. (2013). Modern regional innovation policy. Cambridge Journal of Regions, Economy and Society, 6 (2), pp. 187-216.

McCann, P. and Ortega-Argilés, R. (2017). The intellectual and practical bases of the application of RIS3 within EU cohesion policy. In McCann, P., van Oort, F. and Goddard, J. (eds.) The empirical and institutional dimensions of smart specialisation, pp. 8-22. London: Routledge.

Morgan, K. (2015). Smart specialisation: Opportunities and challenges for regional innovation policy. Regional Studies, 49 (3), pp. 480-482.

Morgan, K. (2017a). Nurturing novelty: Regional innovation policy in the age of smart specialisation. Environment and Planning C: Politics and Space, 35 (4), pp. 569-583.

Morgan, K. (2017b). Speaking truth to power: The political dynamics of public sector innovation. In Kyriakou, D., Martínez, M. P., Periáñez-Forte, I. and Rainoldi, A. (eds.) Governing smart specialisation, pp. 49-61. London: Routledge.

Mäenpää, A. and Lundström, N. (2019). Entrepreneurial discovery process through wicked game approach. Civil society engagement as a possibility for exploration. In Mariussen, Å., Virkkala, S., Finne, H. and Aasen, T. M. (eds.) The entrepreneurial discovery process and regional development: New knowledge emergence, conversion and exploitation. Abingdon: Routledge.

Nauwelaers, C., Magro, E., Aranguren, M. J., Navarro, M., Wilson, J., Trippl, M., Hansen, T., Grillitsch, M., Blažek, J., Morgan, K. and Healy, A. (2015). Underpinning effective strategy design. Research Working Paper. [Cardiff]: [Cardiff University].

Nguyen, N. and Mariussen, $\AA$. (2019). Moving beyond related variety, creating firm level ambidexterity for economic growth via entrepreneurial discovery process. In Mariussen, $\AA$., Virkkala, S., Finne, H. and Aasen, T. M. (eds.) The entrepreneurial discovery process and regional development: New knowledge emergence, conversion and exploitation. Abingdon: Routledge.

Radosevic, S. (2017a). Advancing theory and practice of smart specialisation: key messages. In Radosevic, S., Curaj, A., Gheorghiu, R., Andreescu, L. and Wade, I. (eds.) Advances in the theory and practice of smart specialization, pp. 345-355. London: Academic Press.

Radosevic, S. (2017b). Assessing EU smart specialization policy in a comparative perspective. In Radosevic, S., Curaj, A., Gheorghiu, R., Andreescu, L. and Wade, I. (eds.) Advances in the theory and practice of smart specialization, pp. 1-36. London: Academic Press.

Rinkinen, S. and Harmaakorpi, V. (2017). The business ecosystem concept in innovation policy context: building a conceptual framework. Innovation: The European Journal of Social Science Research, pp. 1-17.

Rodríguez-Pose, A. and Wilkie, C. (2017). Institutions and the entrepreneurial discovery process for smart specialization. In Kyriakou, D., Martínez, M. P., Periáñez-Forte, I. and Rainoldi, A. (eds.) Governing smart specialisation, pp. 34-48. London: Routledge.

Rodrik, D. (2004). Industrial policy for the twenty-first century. Faculty Research Working Papers Series. Cambridge MA: Harvard University, John F. Kennedy School of Government.

Rodrik, D. (2007). One economics, many recipes. Globalization, institutions and economic growth. Princeton: Princeton University Press.

Rodrik, D. (2014). Green industrial policy. Oxford Review of Economic Policy, 30 (3), pp. 469-491.

Sabel, C. F. (1993). Learning by monitoring: The institutions of economic development. [CLESCUSL] Working paper 102. Cambridge MA: MIT.

Sabel, C. F. and Zeitlin, J. (2010). Learning from difference: the new architecture of experimentalist governance in the EU. In Sabel, C. F. and Zeitlin, J. (eds.) Experimentalist governance in the European Union: towards a new architecture, pp. 1-28. Oxford: Oxford University Press.

Schumpeter, J. A. (1934). The theory of economic development. An inquiry into profits, capital, credit, interest, and the business cycle. Cambridge MA: Harvard University Press. 
Shane, S. (2003). A general theory of entrepreneurship. The individual-opportunity nexus. Northampton MA: Edward Elgar.

Sotarauta, M. and Pulkkinen, R. (2011). Institutional entrepreneurship for knowledge regions: in search of a fresh set of questions for regional innovation studies. Environment and Planning C: Government and Policy, 29 (1), pp. 96-112.

Tödtling, F. (2011).Endogenous approaches to local and regional development policy. in A. Pike, A. Rodríguez-Pose and J. Tomaney (eds.): Handbook of Local and Regional Development, 333343, London: Routledge.

Virkkala, S. (2019). Entrepreneurial discovery process, knowledge creation and knowledge space. In Mariussen, Å., Virkkala, S., Finne, H. and Aasen, T. M. (eds.) The entrepreneurial discovery process and regional development: New knowledge emergence, conversion and exploitation. Abingdon: Routledge.

Virkkala, S. and Mariussen, Å. (2019). Emergence through entrepreneurial discovery processes: From place-based strategies to transnational networks. In Mariussen, Å., Virkkala, S., Finne, H. and Aasen, T. M. (eds.) The entrepreneurial discovery process and regional development: New knowledge emergence, conversion and exploitation. Abingdon: Routledge.

Virkkala, S., Mäenpää, A. and Mariussen, Å. (2017). A connectivity model as a potential tool for smart specialization strategies. European Planning Studies, 25 (4), pp. 661-679.

Wenger, E. (1998). Communities of practice. Learning, meaning, and identity. Cambridge: Cambridge University Press. 